\title{
The Characterization and Testing Liquid Soap Nanoparticles of Tamarillo Extract as Antioxidants
}

\author{
W Wirasti ${ }^{1}$, Yulian Wahyu Permadi ${ }^{2}$, Wulan Agustin Ningrum ${ }^{3}$ \\ \{wirasti.kharis@gmail.com ${ }^{1}$ \} \\ Pharmacy, Universitas Muhammadiyah Pekajangan Pekalongan, 51172, Indonesia ${ }^{1,2,3}$
}

\begin{abstract}
The technology of nanoparticles is a formulating technology of a particle which dispersed on the nanometer size or scale per thousand microns. This study aims to characterization and produce the liquid soap preparation from nanoparticles of 'terong belanda' extract which is very good for the antioxidants. This technology has very significant effect as the antioxidants, so it possibly produced as cosmetic ingredients. The extraction method used here is maceration using of methanol solvent. Meanwhile, the making of technology of 'terong belanda' extract nanoparticles used biopolymer-based nanoparticle method. It was formulated as a liquid soap. The result of particle size analysis is extract nanoparticle for about $183,4 \mu \mathrm{m}$, the size of the nanoparticles in liquid soap has achieved $186.2 \mu \mathrm{m}$. Moreover, the result of antioxidants activity test which was conducted by the free radical scavenger method of DPPH obtained IC50 nanoparticle liquid soap preparation of $47 \mathrm{mg} / \mathrm{ml}$, compared with scorbut acid IC50 at $49 \mathrm{mg} / \mathrm{ml}$. Water content liquid soap nanoparticles tamarillo extract is $7,4 \%$ Besides, the results of the stability test for liquid soap nanoparticles, consisting pH 8.3- 8.6, viscosity (3928 - 3930 poise), Foam stability power test is 85.87 and $89 \%$, stated there is no consistency changing of each formula. From organoleptic test, it resulted a light yellow from 'terong belanda' color, a characteristic soap odor and a physical condition with thick / semi-solid consistency. The last, it could be concluded from the nanoparticles liquid soap testing; there is no changing of nanoparticles size. However, it resulted a strong antioxidant power and the stability of the preparation meets the SNI requirements.
\end{abstract}

Keywords: Liquid soap nanoparticles, Tamarillo extract, Antioxidants

\section{Introduction}

Tamarillo fruits is a domestic commodity that has good potential to be developed. Therefore, research is needed to make use of tamarillo so that it is easily distributed and promoted. This fruit is mostly consumed as fruit, whether it is used fresh, made in syrup, or juice. Other than that, may be useful for cosmetics. The use of cosmetic preparations in the form of nanoparticles is developing.

The technology of nanoparticles is a formulating technology of a particle which dispersed on the nanometer size or scale per thousand microns. This study aims to characterization and produce the liquid soap nanoparticles of tamarillo extract as antioxidants. This study aims to characterization and produce the liquid soap nanoparticles of tamarillo extract as antioxidants.

The contribution of this research is development of nanoparticles in natural ingredients that are useful for cosmetics, thus increasing innovation in cosmetic preparations. The use of cosmetic preparations of nanoparticles is still possible to develop more widely, considering that 
now every human being, whether male or female, needs cosmetics according to their portion for their appearance every day.

\section{Method}

\subsection{Equipment and Materials}

Equipment used is blender, oven, sieve mesh 40, glass jar, spoon, evaporator, stirrer magnetic, sentrifuge, baker glass, analytical balance, filter paper, Particle Size Analyzer (PSA), Scanning Electron Microscopy (SEM), mortir, pH meter, viskometer ostwald, piknometer, test tube, microscope. Materials used is atsiri oils $3 \%$, VCO $30 \mathrm{gr}, \mathrm{NaOH}$ 5,1 gr, $\mathrm{NaCl}$ 0,2 gr, Sitrit acis $0,3 \mathrm{gr}$, Stearic acid $5 \mathrm{gr}$, Aquadest $15 \mathrm{~mL}$, alcohol 96\%, gliserin, glucose solution, coloring and fragrance to taste.

\subsection{Preparation of nanoparticles extract tamarillo}

The amount of 1 gram extract was dissolved in $35 \mathrm{~mL}$ of ethanol pa mixed with $15 \mathrm{~mL}$ of distilled water in a $2000 \mathrm{ml}$ glass beaker, then added $100 \mathrm{~mL}$ of chitosan solution in $1 \%$ glacial acetic acid solution. Then add $350 \mathrm{ml}$ of NaTPP gradually to the mixture, while stirring with a magnetic stirrer at a stable speed for 2 hours [1]. After all the ingredients are mixed with colloid nanoparticles, chitosan NaTPP, tamarillo extract is separated by centrifugation of the solids obtained and then put in a freezer $\pm 4^{\circ} \mathrm{C}$ for \pm 2 days. Storage is moved in a refrigerator \pm 3 degrees Celsius until dry [1], which is then dried by spray dying so that a dry powder of ethanol extract nanoparticles is obtained [3].

\subsection{Nanoparticles characterization}

The nanoparticles characterization of the ethanol extract of tamarillo was characterized using a Particle Size Analyzer and a zeta sizer (PSA) to determine the particle size and zeta potential value of tamarillo extract nanoparticles [4]. The Particle Size Analyzer is able to measure particles ranging from $0.02 \mathrm{~nm}$ to $2000 \mathrm{~nm}$ [5]. The particle size is calculated based on the Stokes-Einstein correlation function and the brown motion is defined as the translational diffusion coefficient so as to produce a size distribution in intensity, number and volume [4].

\subsection{Preparation Liquid soap Nanoparticle's tamarillo extract}

Liquid soap Nanoparticle's tamarillo extract containing 3 formulas with different concentration variations as presented in Table 1. 
Tabel 1. Liquid Soap Nanoparticle tamarillo extract

\begin{tabular}{clccc}
\hline $\mathrm{N}$ & \multicolumn{1}{c}{ Materials } & \multicolumn{3}{c}{ Formulas and composition (\%) } \\
\cline { 3 - 5 } $\mathrm{O}$ & & $\mathrm{F} 1$ & $\mathrm{~F} 2$ & $\mathrm{~F} 3$ \\
\hline 1 & Tamarillo Nanoparticles extract & 10 & 15 & 20 \\
2 & Sodium Lauryl Sulfate & 18,5 & 18,5 & 18,5 \\
3 & $\mathrm{NaCl}$ & 5 & 5 & 5 \\
4 & Propylene Glycol & 1 & 1 & 1 \\
5 & Sitrit Acid & 0,5 & 0,5 & 0,5 \\
6 & Aquadest & $\mathrm{ad} 100$ & $\mathrm{ad} \mathrm{100}$ & $\mathrm{ad} 100$ \\
\hline
\end{tabular}

The method of preparation is $\mathrm{Na}$ Lauril Sulfate mixed with $\mathrm{NaCl}$, stirring until homogeneous. The mixture was added with citric acid and propylene glycol, then added with aqua destilata and tamarillo extract nanoparticles, stirring until homogeneous. After all the ingredients are mixed, the volume is sufficient using aqua destilata to $100 \mathrm{~mL}$ [4].

Antioxidant test. $0.5 \mathrm{ml}$ of sample solution from various concentrations (10 ppm, $50 \mathrm{ppm}$, $100 \mathrm{ppm}$ and $150 \mathrm{ppm}$ and $200 \mathrm{ppm}$ ) then each one is added with $3.5 \mathrm{ml}$ of DPPH. Then, vortexed and incubated on temperature $37^{\circ} \mathrm{C}$ in a dark room. Be measured absorbance at a wavelength of $517 \mathrm{~nm}$.

Test The Preparation. Organoleptic test, Observed the consistence, color and aroma of the liquid soap preparation.

Water Content test. Water content in Liquid soap nanoparticles used moisture meter.

Homogeneity test. Take a little dosage form of the formula, then put a little dosage between the two slides. The arrangement of coarse or inhomogeneous particles is observed.

pH test. $\mathrm{pH}$ test is carried out by preparing each sample preparation. The electrodes are immersed in the preparation until the $\mathrm{pH}$ meter shows a steady reading. Record the results of the examination.

Viscosity test. Viskositas testing used Viscosimeter Rionseri VT 04 rotor no 2.

Foam Stability power test. The height of liquid soap solution stirred at speed certain magnetic uses stirrer measured high foam formed measured and observed each week for 6 weeks.

Cycling test. The cycling test is an accelerated test by storing the sample at $24^{\circ} \mathrm{C}$ for 24 hours, then transferring it to an oven at $40^{\circ} \mathrm{C}$ for 24 hours. This treatment is 1 cycle. The treatment was repeated for 6 cycles, observations were made with organoleptic parameters, homogeneity, $\mathrm{pH}$, spreadability, and viscosity [5].

\section{Results and Discussion}

\subsection{Result}

The DPPH test results were $50 \%$ inhibitory concentration $\left(\mathrm{IC}_{50}\right)$ of free radical nanoparticle liquid soap of $47 \mathrm{mg} / \mathrm{mL}$ and IC50 of vitamin C was $49 \mathrm{mg} / \mathrm{mL}$. Test DPPH result are shown in Figure 1. 


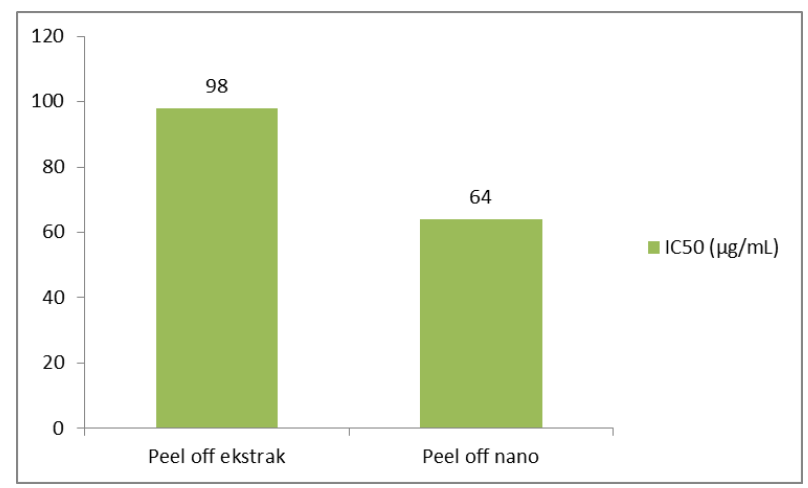

Fig. 1. result test antioksidant

The homogeneity of liquid soap nanoparticles tamarillo extract from the first week to the third week, the results were stable, namely good homogeneity. In accordance with SNI standards that product homogeneity must always be good. The homogeneity test result are shown in the Table 2.

Table 2. result of homogeneity test

\begin{tabular}{lccc}
\hline Formula & \multicolumn{3}{c}{ week } \\
\cline { 2 - 4 } & $\mathbf{1}$ & $\mathbf{2}$ & $\mathbf{3}$ \\
\hline I & Homogen & Homogen & Homogen \\
II & Homogen & Homogen & Homogen \\
III & Homogen & Homogen & Homogen \\
\hline
\end{tabular}

The result of this test is that all formulas produce the same viscosity in the same week. The change in viscosity for each week increases by 1 poise, but is still within the SNI requirement range (less than 20,000 poise). So that it can be concluded that the viscosity is included in the SNI requirements. The results of viscosity test are shown in the Table 3.

Table 3. Result of viscosity test

\begin{tabular}{lccc}
\hline Formula & \multicolumn{3}{c}{ Week } \\
\cline { 2 - 4 } & $\mathbf{1}$ & $\mathbf{2}$ & $\mathbf{3}$ \\
\hline I & 3928 & 3929 & 3931 \\
II & 3928 & 3929 & 3931 \\
III & 3928 & 3929 & 3931 \\
\hline
\end{tabular}

\subsection{Discussion}

Zeta potensial describes the potential for nanoparticle molecules to move away from each other or clump together. The normal value of zeta potential is $<30 \mathrm{mV}$, or more than $>30 \mathrm{mV}$ [7]. The result of making tamarillo nanoparticles is $-8.3 \mathrm{mV}$, thus allowing these nanoparticles to settle easily, so the next preparation must be done immediately. The ideal nanoparticle size is 1-1000 micro [6]. The result of measuring the nanoparticles of tamarillo was $182.4 \mathrm{um}$. The measurement result of nanoparticles from liquid soap was $186.2 \mu \mathrm{m}$. The nanoparticle particle size is relatively unchanged. This is because the soap making is not overheated, so the particle size is relatively stable. 
Antioxidant testing is intended to test the activity of a sample against antioxidant or antifree radical power Antioxidant testing uses DPPH. DPPH is a stable free radical compound so that if it is used as a reagent in the free radical scavenging test, it is sufficient to dissolve it and when it is stored in dry conditions with good and stable storage conditions for years. DPPH absorbance values ranged from 515-520 nm. DPPH free radical reduction method is based on reduction of colored DPPH free radical methanol solution by free radical inhibition. When the purple DPPH solution meets the electron donor material, the DPPH will be reduced, causing the purple color to fade and be replaced by a yellow color coming from the picryl group. The DPPH test results were 50\% inhibitory concentration (IC50) of free radical nanoparticle liquid soap of $47 \mathrm{mg} / \mathrm{mL}$ and IC50 of vitamin C was $49 \mathrm{mg} / \mathrm{mL}$.

Organoleptic test carried out on liquid soap nanoparticles tamarillo extract is test of the aroma, color and form/consistency of the soap [8]. This test was carried out for 3 weeks. The result of this test are Aroma: Formula 1,2, and 3, there was no change in smell / aroma during the 3 week observation. The aroma produced is the distinctive smell of soap.

Color: In the observation of colors in formulas 1,2 and 3 for 3 weeks, a constant color is produced. The first, second- and third-week colors are the same / there is no color change.

Form / Consistency: The consistency or form of semi-solid / viscous tamarillo nanoparticles liquid soap. The observation for 3 weeks resulted that there was no change.

The homogeneity pf liquid soap nanoparticles tamarillo extract from the first week to the third week, the results were stable, namely good homogeneity. In accordance with SNI standards that product homogeneity must always be good.

The result of tes $\mathrm{pH}$ of formulas 1,2, and 3 liquid soap nanoparticles of tamarillo extract ranged from 8.3 to 8.6. The results obtained are in accordance with SNI standards for $\mathrm{pH}$ of skin preparations 8-11. Formula 1 has a lower $\mathrm{pH}$ because the composition of formula 1 has a lower level of active substance with the same solvent.

The purpose of the viscosity test was to determine the stability of liquid soap nanoparticles tamarillo extract in viscosity parameters. The result of this test is that all formulas produce the same viscosity in the same week. The change in viscosity for each week increases by 1 poise, but is still within the SNI requirement range (less than 20,000 poise). So that it can be concluded that the viscosity is included in the SNI requirements. The results of the viscosity test are shown in the table 3.

Foam stability is a condition in which a soap preparation has a relatively constant foam, so that the lathering power of the preparation is constant. In accordance with the Indonesian National Standard, the stability of the foam is not less than $70 \%(<70 \%)$. The results of the foam stability observations from formulas 1,2 and 3 were $85 \%, 87 \%$ and $89 \%$, respectively. The results of this observation are in accordance with the SNI regulation.

Used to test the water content in the liquid soap nanoparticle tamarillo extract. The water content required for liquid soap is less than $10 \%(<10 \%)$. The water content produced in the liquid soap nanoparticles of tamarillo extract is $7.4 \%$, so that this water content is in accordance with SNI and Indonesian pharmacopoeia requirements.

\section{Conclusion}

The IC50 value of liquid soap nanoparticle is $47 \mu \mathrm{g} / \mathrm{ml}$. The particle size of nanoparticle extract was $182.4 \mu \mathrm{m}$ and the particle size of the liquid soap nanoparticle is $186 \mu \mathrm{g} / \mathrm{ml}$. Liquid soap nanoparticle Tamarillo extract has a moisture content of 7.4\%, $\mathrm{pH} 8.3-8.9$, foam stability 
test of 85.87 , and $89 \%$, viscosity of $3928-3931$ poise, homogeneous consistency and organoleptic (aroma, color, consistency) is stable. It is necessary to make other dosage forms for cosmetic.

\section{Acknowledgement}

We would like to thank the head of the institute for research, community service innovation and creativity, Universitas Muhammadiyah Pekajangan Pekalongan for the financial support provided so that this research can be completed smoothly.

\section{References}

[1] essy Kurniasari and Sri Atun, 'Pembuatan Dan Karakterisasi Nanopartikel Ekstrak Etanol Temu Kunci (Boesenbergia Pandurata) Pada Berbagai Variasi Komposisi Kitosan', Jurnal Sains Dasar, 6.1 (2017), 31 https://doi.org/10.21831/jsd.v6i1.13610

[2] Kun Tanti Dewandari, S Yuliani, and Yasni, 'Ekstraksi Dan Karakterisasi Nanopartikel Ekstrak Sirih Merah (Piper Crocatum)', Jurnal Pascapanen, 2013, 58-65

[3] Rafika Sari and Ade Ferdinan, 'Antibacterial Activity Assay of the Liquid Soap from the Extract of Aloe Vera Leaf Peel', Pharmaceutical Sciences and Research, 4.3 (2017), 111-20 <https://doi.org/10.7454/psr.v4i3.3763>.

[4] Marline Abdassah, 'Nanopartikel Dengan Gelasi Ionik', Farmaka, 15.1 (2009), 45-52.

[5] Sandra N Whetstone, Perfumes, Cosmetics and Soaps, Journal of AOAC INTERNATIONAL, 1976, LIX <https://doi.org/10.1093/jaoac/59.5.1193a>.

[6] Martien, Ronny, Adhyatmika, Iramie D. K Irianto, Verda Farida, and Dian Puwita Sari, 2012, Perkembangan Teknologi Nanopartikel Sebagai Sistem Penghantaran Obat, Majalah Farmaseutik, $8.1,133-44$

[7] V J Mohanraj and Y Chen, 'Nanoparticles - A Review', Tropical Journal of Pharmaceutical Research, 5.1 (2007), 561-73 <https://doi.org/10.4314/tjpr.v5i1.14634>.

[8] Sudaryanto Zain Asri Widyasanti, Anisa Yanthy Rahayu, 'P Embuatan S Abun C Air B Erbasis V Irgin C Oconut O Il ( Vco ) Dengan P Enambahan M Inyak M Elati ( J Asminum S Ambac ) S Ebagai E Ssential O IL Liquid Soap Making From Virgin Coconut Oil ( VCO ) -Based With Jasmine Oil ( Jasminum Sambac ) As Sabun Merup', Jurnal Teknotan, 11.2 (2017), 1-10 